\title{
Serum Levels of Surfactant Proteins in Patients with Combined Pulmonary Fibrosis and Emphysema (CPFE)
}

\author{
Andriana I. Papaioannou ${ }^{1}$ *, Konstantinos Kostikas ${ }^{1}$, Effrosyni D. Manali ${ }^{1}$, \\ Georgia Papadaki ${ }^{1}$, Aneza Roussou ${ }^{1}$, Aris Spathis ${ }^{2}$, Argyro Mazioti ${ }^{3}$, Ioannis Tomos ${ }^{1}$, \\ Ilias Papanikolaou ${ }^{4}$, Stelios Loukides ${ }^{1}$, Kyriakos Chainis ${ }^{4}$, Petros Karakitsos ${ }^{2}$, \\ Matthias Griese ${ }^{5}$, Spyros Papiris ${ }^{1}$
}

1 2nd Respiratory Medicine Department, "Attikon" University Hospital, Athens Medical School, National and Kapodistrian University of Athens, Athens, Greece, 2 Department of Cytopathology, "Attikon" University Hospital, Athens Medical School, National and Kapodistrian University of Athens, Athens, Greece,

3 Department of Radiology, "Attikon" University Hospital, Athens Medical School, National and Kapodistrian University of Athens, Athens, Greece, 4 Respiratory Medicine Department, "Corfu General Hospital”, Corfu, Greece, 5 Hauner Children's University Hospital, Ludwig-Maximilians-University, German Center for Lung Research, Lindwurmstrasse 4, 80337, Munich, Germany

* papaioannouandriana@gmail.com

\section{Abstract}

\section{G openaccess}

Citation: Papaioannou Al, Kostikas K, Manali ED, Papadaki G, Roussou A, Spathis A, et al. (2016) Serum Levels of Surfactant Proteins in Patients with Combined Pulmonary Fibrosis and Emphysema (CPFE). PLoS ONE 11(6): e0157789. doi:10.1371/ journal.pone.0157789

Editor: Yunchao Su, Augusta University, UNITED STATES

\section{Received: March 22, 2016}

Accepted: June 3, 2016

Published: June 23, 2016

Copyright: @ 2016 Papaioannou et al. This is an open access article distributed under the terms of the Creative Commons Attribution License, which permits unrestricted use, distribution, and reproduction in any medium, provided the original author and source are credited.

Data Availability Statement: All relevant data are within the paper.

Funding: The manuscript has been supported by the Greek State Scholarship Foundation -Fellowships of Excellence- Siemens.

Competing Interests: The authors have declared that no competing interests exist.

\section{Introduction}

Emphysema and idiopathic pulmonary fibrosis (IPF) present either per se or coexist in combined pulmonary fibrosis and emphysema (CPFE). Serum surfactant proteins (SPs) A, B, C and $D$ levels may reflect lung damage. We evaluated serum SP levels in healthy controls, emphysema, IPF, and CPFE patients and their associations to disease severity and survival.

\section{Methods}

122 consecutive patients ( 31 emphysema, 62 IPF, and 29 CPFE) and 25 healthy controls underwent PFTs, ABG-measurements, 6MWT and chest HRCT. Serum levels of SPs were measured. Patients were followed-up for 1-year.

\section{Results}

SP-A and SP-D levels differed between groups ( $p=0.006$ and $p<0.001$ respectively). In post-hoc analysis, SP-A levels differed only between controls and CPFE $(p<0.05)$ and CPFE and emphysema ( $p<0.05)$. SP-D differed between controls and IPF or CPFE $(p<0.001$ for both comparisons). In IPF SP-B correlated to pulmonary function while SP-A, correlated to the Composite Physiological Index (CPI). Controls current smokers had higher SP-A and SP-D levels compared to non-smokers ( $p=0.026$ and $p=0.023$ respectively). SP-D levels were higher in CPFE patients with extended emphysema $(p=0.042)$. In patients with IPF, SP-B levels at the upper quartile of its range $(\geq 26 \mathrm{ng} / \mathrm{mL})$ presented a weak association with reduced survival $(p=0.05)$. 


\section{Conclusion}

In conclusion, serum SP-A and SP-D levels were higher where fibrosis exists or coexists and related to disease severity, suggesting that serum SPs relate to alveolar damage in fibrotic lungs and may reflect either local overproduction or overleakage. The weak association between high levels of SP-B and survival needs further validation in clinical trials.

\section{Introduction}

Pulmonary emphysema and idiopathic pulmonary fibrosis (IPF) are two distinct entities defined by different clinical, functional, radiological, and pathological criteria [1]. IPF is the most common of the idiopathic interstitial lung diseases (i-ILDs) and has the histopathologic and/or radiologic pattern of usual interstitial pneumonia (UIP) [2], while emphysema is defined as an enlargement of the air spaces distal to the terminal bronchioles due to the destruction of tissues forming their walls [3]. These two entities coexist in a condition characterized by upper lobe emphysema and lower lobe pulmonary fibrosis, which is known as combined pulmonary fibrosis and emphysema (CPFE) $[1,4]$. The coexistence of the two conditions, which have different pathophysiological and functional characteristics, results in the development of a disease entity, with distinct clinical and functional characteristics and different prognosis compared to its individual components [5].

Pulmonary surfactant is a highly surface-active mixture of proteins and lipids that is synthesized and secreted onto the alveoli by type II epithelial cells $[6,7]$. The protein part of surfactant constitutes of four types of surfactant proteins (SP), SP-A, SP-B, SP-C and SP-D. SP-A and SP-D are hydrophilic proteins that regulate surfactant metabolism and have immunologic functions, whereas SP-B and SP-C are hydrophobic molecules, which play a direct role in the organization of the surfactant structure in the interphase and in the stabilization of the lipid layers during the respiratory cycle [8, 9]. Different polymorphisms of SP-A [10], and SP-B [10-13] genes and mutations in SP-C [14] genes have been related to COPD. Furthermore, studies have shown that circulating SP-A and SP-D levels were increased in patients with COPD compared to normal smokers and non-smoking controls and correlated to airway obstruction [15-17]. On the other hand, there is evidence showing a possible role of surfactant proteins in the development of ILDs. Infants and children with mutations in the genes encoding surfactant proteins develop such a disease early in their life [18], while mutations of SP-A and C genes are associated with familial interstitial lung disease [19-23]. Serum levels of SP-D have been shown to be higher in patients with IPF compared to control subjects $[24,25]$. Furthermore, serum SP-D concentrations are related to the annual rate of deterioration of pulmonary function [26], while high serum levels of SP-A and SP-D seem to be predictors of rapid disease deterioration and have been associated with poor survival in patients with IPF $[25,27,28,29]$. Finally, there is evidence than SP-C gene mutations are associated with CPFE [30-33], while SP-D has been reported to correlate to pulmonary function in these patients [34].

According to the above, we hypothesized that in patients with CPFE, SP would be more disturbed in comparison to patients with only IPF and patients with only emphysema in a clinically significant way. The aim of the present study was to evaluate serum levels of Surfactant Proteins (A, B, C and D) in patients with CPFE, emphysema only, IPF only, and healthy controls and to test their possible associations to pulmonary function, disease severity, and survival. 


\section{Methods \\ Subjects}

From February 2013 to December 2014 we enrolled 147 consecutive patients (31 with emphysema, 62 with IPF, and 29 with CPFE) and 25 healthy controls (smokers and non-smokers). All study subjects were in stable condition and did not report any exacerbation or respiratory tract infection during the last 8 weeks. Patients with $\alpha_{1}$-antitrypsin deficiency, connective tissue disease at the time of diagnosis of CPFE, diagnosis of other interstitial lung disease (such as drug induced ILDs, pneumoconiosis, hypersensitivity pneumonitis, sarcoidosis, pulmonary histiocytosis, LAM, and eosinophilic pneumonia), patients unable to perform PFTs, as well as patients with inability or unwillingness to collaborate with the investigators were not included in the study. All subjects were followed up for one year and their vital status has been recorded.

\section{Study design}

All patients provided a detailed history upon arrival, and underwent physical examination and blood samples collection. Subsequently they were submitted to pulmonary function tests, measurement of body mass index (BMI) and evaluation of exercise capacity using the 6 minutes walking test. Arterial blood gases were also measured. Finally, all patients underwent high resolution computed tomography of the chest (HRCT). The study protocol was approved by the ethics committee of “Attikon” University Hospital, Chaidari Athens Greece and all patients gave written informed consent.

\section{Pulmonary Function Tests}

Pulmonary function tests (PFTs) were performed with commercially available system (Master Screen, Erich Jaeger GmbH, Wuerzburg, Germany) and included post-bronchodilator forced expiratory volume in one second $\left(\mathrm{FEV}_{1}\right), \mathrm{FVC}, \mathrm{FEV}_{1} / \mathrm{FVC}$ ratio, total lung capacity (TLC), residual volume (RV), inspiratory capacity (IC) and diffusing capacity for carbon monoxide $\left(\mathrm{DL}_{\mathrm{CO}}\right)$. Diffusing capacity for carbon monoxide $\left(\mathrm{DL}_{\mathrm{CO}}\right)$ and diffusing capacity for carbon monoxide adjusted for alveolar volume $\left(\mathrm{DL}_{\mathrm{CO}} / \mathrm{V}_{\mathrm{A}}\right)$ were assessed by means of the single breath method with the patient in the sitting position. Lung function measurements were expressed as percentages of predicted values. Tests were performed according to the American Thoracic Society guidelines [35] by the same technician in order to ensure consistency of the results.

The composite physiologic index that is associated to mortality in IPF and CPFE [36] was [calculated according to the following formula: $91.0-(0.65 \mathrm{x}$ percent predicted diffusing capacity for carbon monoxide [DLCO] $)-(0.53 \times$ percent predicted $\mathrm{FVC})+(0.34 \mathrm{x}$ percent predicted $\left.\mathrm{FEV}_{1}\right)$ ][37] was determined in all subjects [38]. In all patients, arterial blood samples were taken for the measurement of $\mathrm{PaO}_{2}$ and $\mathrm{PaCO}_{2}$ using a commercially available blood gas analyzer (model 1630; Instrumentation Laboratories, Milan Italy)

\section{HRCT}

All patients underwent HRCT using Brilliance CT 64-channel scanner (Philips, Eindhoven, the Netherlands). Scans were performed with $1-1.5 \mathrm{~mm}$ section thickness and a 1-2 sec scanning time during breath holding at end inspiration. Films were read by a radiologist with expertise in HRCT who was blinded to the rest of the measurements. The degree of emphysema and/or fibrosis was calculated using a visual score as previously described [39, 40], using a five-point scale based on the percentage of lung involved: 0 : no emphysema/fibrosis; 1 : up to $25 \%$ of the lung parenchyma involved; 2 : between $26-50 \%$ of lung parenchyma involved; 3 : between $26-$ $75 \%$ of the lung parenchyma involved; and 4 between $76-100 \%$ of lung parenchyma involved. 
Grades of the axial images of each lung were added and divided by the number of images evaluated to yield emphysema and/or fibrosis scores that ranged from 0 to $4[39,40]$. The percentage of destructed lung area (\%DLA) was obtained by summing \%emphysema and \%fibrosis [41]. The presence of emphysematous lesions $\geq 15 \%$ (i.e. score $\geq 0.6$ ) of the pulmonary parenchyma in CPFE patients was considered as significant $[42,43]$

\section{Assessment of Dyspnea and Exercise Capacity}

Dyspnea was assessed with the modified (5-point) Medical Research Council (MRC) dyspnea scale, as previously described [44]. Exercise capacity was measured with the 6 minutes walk test in a $100 \mathrm{ft}$ corridor, according to the ATS guidelines [45]. The distance walked in 6 minutes, difference in dyspnea according to Borg scale and alterations in oxygen saturation were recorded in each patient.

\section{Blood Samples Collection and Measurements of Surfactant Proteins}

Blood samples were collected from each subject and were immediately centrifuged at $1500 \mathrm{~g}$ for $15 \mathrm{~min}$ at $4^{\circ} \mathrm{C}$ and the supernatant (serum) was stored at $-80^{\circ} \mathrm{C}$ until measurements.

Serum surfactant proteins were measured using commercially available enzyme-immunosorbent assay (ELISA) kits (SP-A, SP-B and SP- C, USCN Life Science, China and, SP-D, Bioventor, Germany) according to the manufacturer's protocol. The lower limits of detection were the following: SP-A: $8.2 \mathrm{pg} / \mathrm{mL}$, SP-B: $0.31 \mathrm{ng} / \mathrm{ml}$, SP-C: $0.112 \mathrm{ng} / \mathrm{mL}$ and SP-D: $0.01 \mathrm{ng} / \mathrm{mL}$.

\section{Statistical analysis}

Normality of distributions was checked with Kolmogorov-Smirnov test. Comparisons between groups were performed with Kruskal-Wallis tests, with appropriate post-hoc tests (Dunn's test). Correlations were assessed using Spearman's rank correlation coefficient. For the avoidance of type I errors during the performance of multiple correlations we have used the correction method described by Benjamini and Hochberg (1995)[46] according to which a pvalue $<0.023$ was considered statistically significant. Group data are expressed as mean \pm SD or as median (interquartile ranges) for normally distributed and skewed data, respectively. Kaplan Meier Curves were created in order to compare survival in patients with low and those with elevated SP levels and the groups were compared using Log Rank test. The $75^{\text {th }}$ percentile of each SP was used as a cut-off point in order to divide the patients in those with elevated SP levels and those with non-elevated SP levels. Graphical presentations of times to events were performed with Kaplan-Meier curves. Results are presented as hazard ratios (HR) with 95\% confidence intervals (CI). With the exception of the multiple correlations, all other p-values $<0.05$ were considered statistically significant. Analysis was performed using SPSS 17 statistical package (SPSS, Chicago, IL) and GraphPad Prism 5 (GraphPad Software Inc, La Jolla, CA, USA).

\section{Results}

We evaluated 184 consecutive patients with either emphysema, IPF and CPFE and 122 of them were eligible to be included in the present study. The flow chart of the study participants is shown in Fig 1. An additional 25 healthy subjects (smokers and non-smokers) were included as healthy controls. The demographic and functional characteristics as well as serum levels of surfactant proteins of the 122 patients and 25 healthy controls included in the study are presented in Table 1. Serum SP-A and SP-D levels significantly differed between groups ( $\mathrm{p}=0.006$ and $\mathrm{p}<0.001$ for SP-A and SP-D, respectively; Fig 2A-2D). In post-hoc analysis, SP-A levels differed significantly only between controls and CPFE $(p<0.05)$ and between CPFE and 


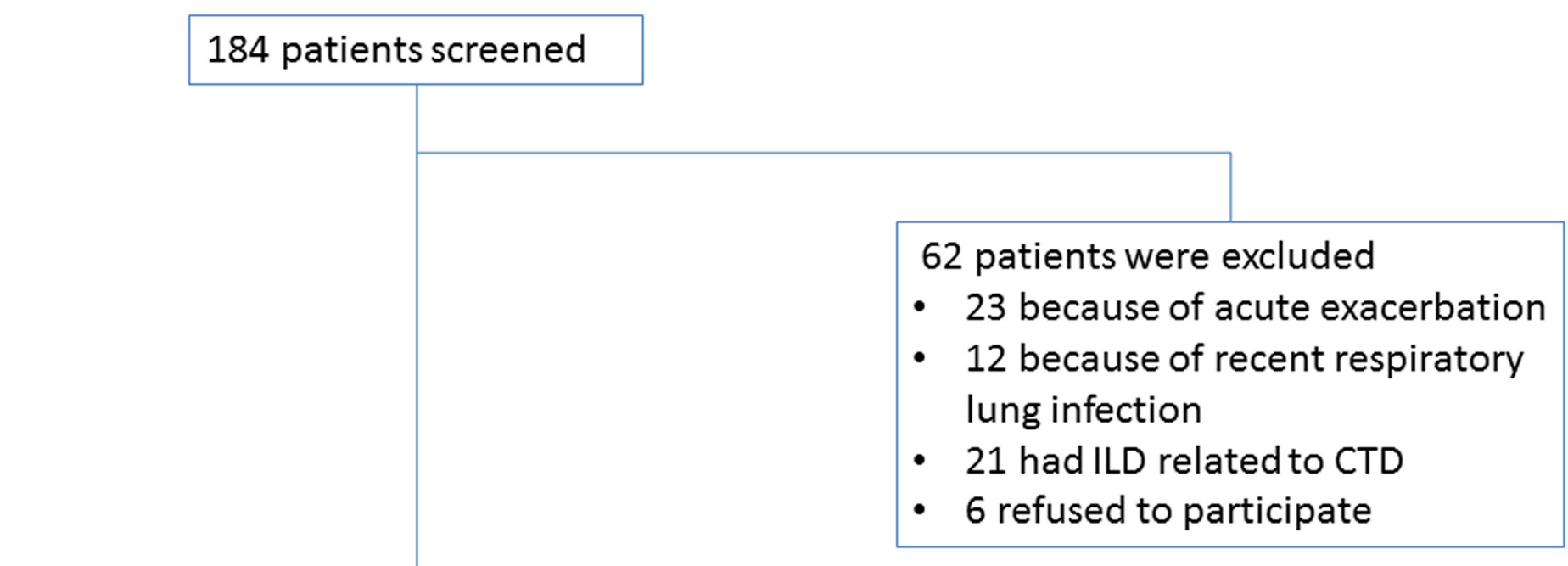

\section{2 patients included to the study}

31 with emphysema

\section{2 with IPF}

\section{9 with CPFE}

\section{5 healthy controls}

Fig 1. Flow chart showing subjects who were finally included to the study.

emphysema $(\mathrm{p}<0.05)$. Similarly, post hoc analysis regarding serum SP-D levels revealed significant differences between controls and fibrosis or CPFE as well as emphysema and fibrosis or CPFE ( $\mathrm{p}<0.001$ for all comparisons).

\section{Correlations of surfactant proteins and pulmonary function tests}

Correlations of surfactant proteins and pulmonary function are shown in Table 2. In patients with fibrosis serum SP-B levels correlated significantly to pulmonary function test results, and specifically to $\mathrm{FEV}_{1}$, FVC, DLCO, TLC, and FRC. The CPI presented only a weak correlation with SP-A ( $p=0.016$; Fig 3A-3D).

\section{SP levels as predictors of survival}

There were limited deaths during the 1-year follow-up in this study, including 8 patients with IPF and 1 patient with emphysema, whereas no control subjects and no patients with CPFE died during the 1-year follow up. Therefore, the potential predictive role of SP levels on survival was evaluated only in patients with IPF. We have evaluated the role of SP levels as predictors of survival in our patients using the $75^{\text {th }}$ percentiles levels as cut-off points, specifically SP-A $\geq 280 \mathrm{ng} / \mathrm{mL}$, SP-B $\geq 26 \mathrm{ng} / \mathrm{mL}, S P-C \geq 1.9 \mathrm{ng} / \mathrm{mL}$, and SP-D $\geq 287 \mathrm{ng} / \mathrm{mL}$. In patients with IPF, SP-B levels above the $75^{\text {th }}$ percentile of $26 \mathrm{ng} / \mathrm{mL}$ were associated with increased mortality ( $p=0.05$ Log rank test; Fig 4). The levels of SP-A, C and D were not related to survival in patients with IPF ( $p=0.642, p=0.632$ and $p=0.623$ for SP-A, SP-C and SP-D respectively). 
Table 1. Demographic and functional characteristics of the study participants.

\begin{tabular}{|c|c|c|c|c|c|}
\hline & Controls N = 25 & $\begin{array}{l}\text { Emphysema only } \\
\mathrm{N}=\mathbf{3 1}\end{array}$ & IPF only $\mathrm{N}=62$ & CPFE N $=29$ & $p$ value \\
\hline Age (years) & $64.0(55.5,67.5)$ & $66.0(59.0,71.0)$ & $72.0(66.8,78.0)$ & $75.0(63.0,77.0)$ & $<0.001$ \\
\hline Gender (Female) N(\%) & $14(56.0 \%)$ & $7(22.6 \%)$ & $19(30.6 \%)$ & $3(10.3 \%)$ & 0.002 \\
\hline BMI kg/m ${ }^{2}$ & $26.7(24.5,29.5)$ & $24.9(21.5,26.8)$ & $27.2(24.5,29.6)$ & $27.9(23.6,29.1)$ & 0.005 \\
\hline $\begin{array}{l}\text { Smoking (current/ex/ } \\
\text { never) }\end{array}$ & 9/5/11 & $18 / 13 / 0$ & $5 / 30 / 27$ & $5 / 22 / 2$ & $<0.001$ \\
\hline Pys & $10.0(0.0,35.0)$ & $70.0(40.0,95.0)$ & $12.5(0.0,36.0)$ & $50.0(30.0,75.0)$ & $<0.001$ \\
\hline FEV $_{1}$ (\%pred) & $92.0(87.5,99.0)$ & $56.4(33.7,79.6)$ & $76.4(65.5,88.1)$ & $76.3(69.5,98.0)$ & $<0.001$ \\
\hline FVC (\%pred) & $90.0(82.0,93.5)$ & $72.8(60.1,93.7)$ & $68.3(57.9,82.1)$ & $68.5(60.3,94.1)$ & 0.001 \\
\hline FEV $_{1} /$ FVC & $82.0(78.5,85.2)$ & $54.4(40.4,69.0)$ & $85.7(81.3,90.8)$ & $79.0(74.4,86.7)$ & $<0.001$ \\
\hline DLCO (\%pred) & $85.0(82.0,88.0)$ & $52.4(36.5,72.0)$ & $46.8(35.2,62.9)$ & $32.0(22.8,46.4)$ & $<0.001$ \\
\hline TLC (\%pred) & $85.0(82.0,87.5)$ & $93.0(81.2,105.8)$ & $59.1(50.2,73.2)$ & $63.4(56.5,78.5)$ & $<0.001$ \\
\hline RV (\%pred) & $83.0(80.5,88.0)$ & $119.0(90.3,126.5)$ & $54.9(43.1,67.4)$ & $57.4(47.9,80.5)$ & $<0.001$ \\
\hline FRC (\%pred) & $83.0(81.0,88.5)$ & $100.0(83.1,129.8)$ & $60.7(52.9,77.1)$ & $67.0(53.5,80.0)$ & $<0.001$ \\
\hline $\mathrm{PO}_{2} / \mathrm{FiO}_{2}$ & $390.5(380.9,392.9)$ & $333.3(300.0,371.4)$ & $352.4(321.4,3711.4)$ & $285.7(258.6,350.0)$ & $<0.001$ \\
\hline 6MWD (m) & $550.0(497.5,551.0)$ & $455.0(300.0,515.0)$ & $459.5(330.0,500.8)$ & $207.0(100.0,424.5)$ & $<0.001$ \\
\hline DLA (\%) & N/A & $1.68(0.6,2.9)$ & $1.5(1.14,2.2)$ & $2.4(1.75,3.3)$ & 0.001 \\
\hline CPI & $20.9(17.7,24.9)$ & $36.5(21.4,51.4)$ & $49.4(36.6,60.2)$ & $57.2(48.3,63.4)$ & $<0.001$ \\
\hline SP-A (ng/ml) & $180.4(118.9,285.2)$ & $193.9(105.8,257.6)$ & $218.0(148.5,293.2)$ & $251.2(225.9,314.1)$ & 0.006 \\
\hline SP-B (ng/ml) & $14.3(6.6,21.3)$ & $17.6(7.2,26.3)$ & $17.9(10.7,25.9)$ & $18.4(11.9,27.3)$ & 0.353 \\
\hline SP-C (ng/ml) & $1.4(0.8,2.2)$ & $1.3(0.7,2.0)$ & $1.2(0.9,1.8)$ & $1.1(0.8,2.1)$ & 0.925 \\
\hline SP-D (ng/ml) & $17.0(7.1,43.6)$ & $35.2(19.1,70.1)$ & $259.8(196.7,333.2)$ & $250.7(181.8,321.0)$ & $<0.001$ \\
\hline
\end{tabular}

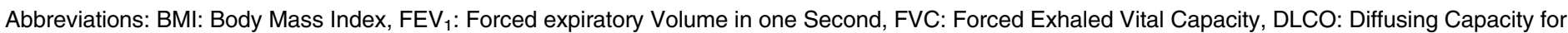
Carbon Monoxide, TLC: Total Lung Capacity, FRC: Functional Residual Capacity, RV: Residual Volume, 6MWD: 6 Minute Walking Distance, DLA: Destructed Lung Area, CPI: Composite Physiological Index, SP: Surfactant Protein, IPF: Idiopathic Pulmonary Fibrosis, CPFE: Combined Pulmonary Fibrosis and Emphysema. Bold represent statistically significant differences.

doi:10.1371/journal.pone.0157789.t001

\section{The effect of smoking on SP levels}

Smoking seemed to influence serum SP-A and SP-D levels only in control subjects. Current smokers had higher serum SP-A and SP-D levels compared to current non-smokers (both never smokers and ex-smokers) $[325.7(152.6,357.0)$ vs $156.3(104.0,188.2), \mathrm{p}=0.026]$ and [41.0 (14.3, 110.2) vs $10.4(5.6,33.3), \mathrm{p}=0.023$ for SP-A and SP-D, respectively]. No differences were observed according to smoking habit regarding SP-B $(\mathrm{p}=0.300)$ and SP-C $(\mathrm{p}=0.508)$ levels (Fig 5A-5D). Furthermore, no significant differences of serum levels of any of the four SPs have been found according to current smoking habit in patients with emphysema, fibrosis or CPFE (data not shown).

\section{The effect of the extend of fibrosis on SP levels}

CPFE patients were divided in two subgroups according to the presence of significant extent of emphysematous lesions: 23 patients were considered to have significant emphysematous lesions (i.e. $\geq 15 \%$ of total lung area) whereas 6 patients had emphysematous lesions $<15 \%$. SP-D levels were significantly higher in CPFE patients with significant extent of emphysema compared to those without significant extent of emphysema [290.7 $(195.5,334.7)$ vs 191.5 (37.65, 244.5), $\mathrm{p}=0.042$ ] for CPFE patients with and without significant extent of emphysematous lesions respectively (Fig 6). SP-A, SP-B and SP-D levels did not differ between these two groups $(\mathrm{p}=0.569, \mathrm{p}=0.309$, and $\mathrm{p}=0.969$ respectively). 
A

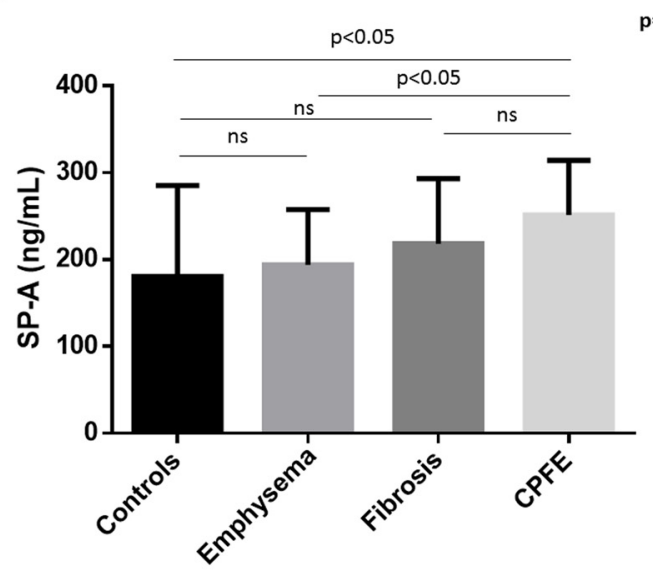

C

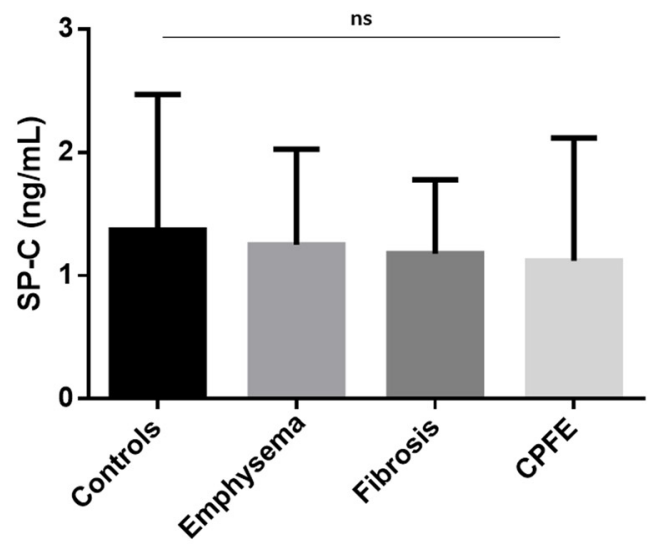

B

$\mathrm{p}=0.006$

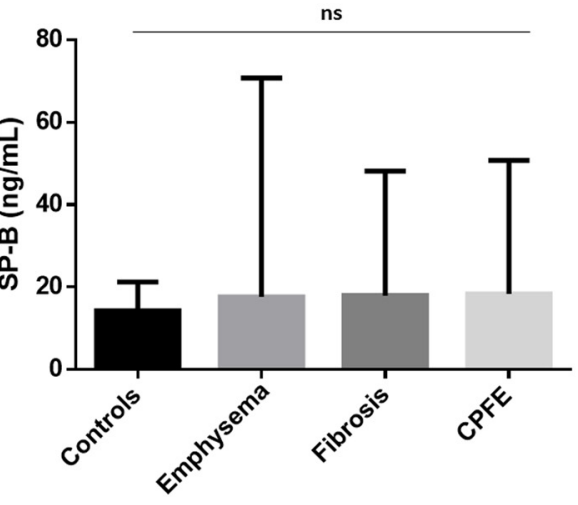

D

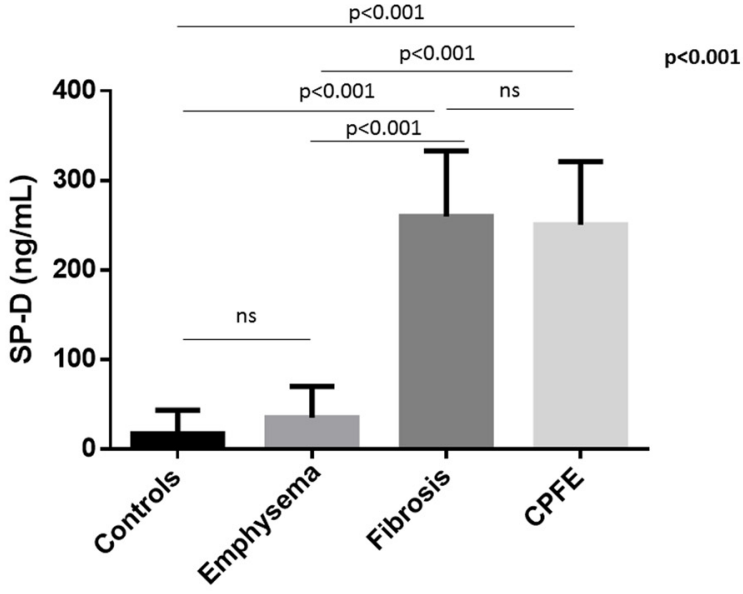

Fig 2. Serum surfactant protein levels in the different study groups. A. SP-A, B. SP-B, C. SP-C, D. SP-D. doi:10.1371/journal.pone.0157789.g002

\section{Discussion}

In this study we have shown that the levels of SP-A and SP-D differ between controls, patients with emphysema, IPF and CPFE, with IPF and CPFE demonstrating the highest values. Serum SP-D levels were also significantly higher in CPFE patients with significant emphysematous component. In patients with IPF serum SP-A, levels significantly correlated also to CPI a composite index of estimation of disease severity and extent. Furthermore, serum SP-A and SP-D levels were increased in healthy smokers compared to non-smokers. Finally, although SP-B did not differ between groups its blood levels in patients with IPF correlated to $\mathrm{FEV}_{1}, \mathrm{FVC}$, DLCO, FRC and TLC and patients in the upper quartile of SP-B values were associated with worse survival. To our knowledge, this is the first study examining the possible differences of the levels of the four SPs in these four groups of patients.

Regarding SP-A and SP-D, our findings confirm previous studies that have shown increased levels in the circulation [24] of patients with fibrosis, although these levels were decreased in the BAL fluid $[22,47]$ but without a significant association between the circulating levels of these proteins and the extent of fibrosis in radiographic studies, a finding that was also 


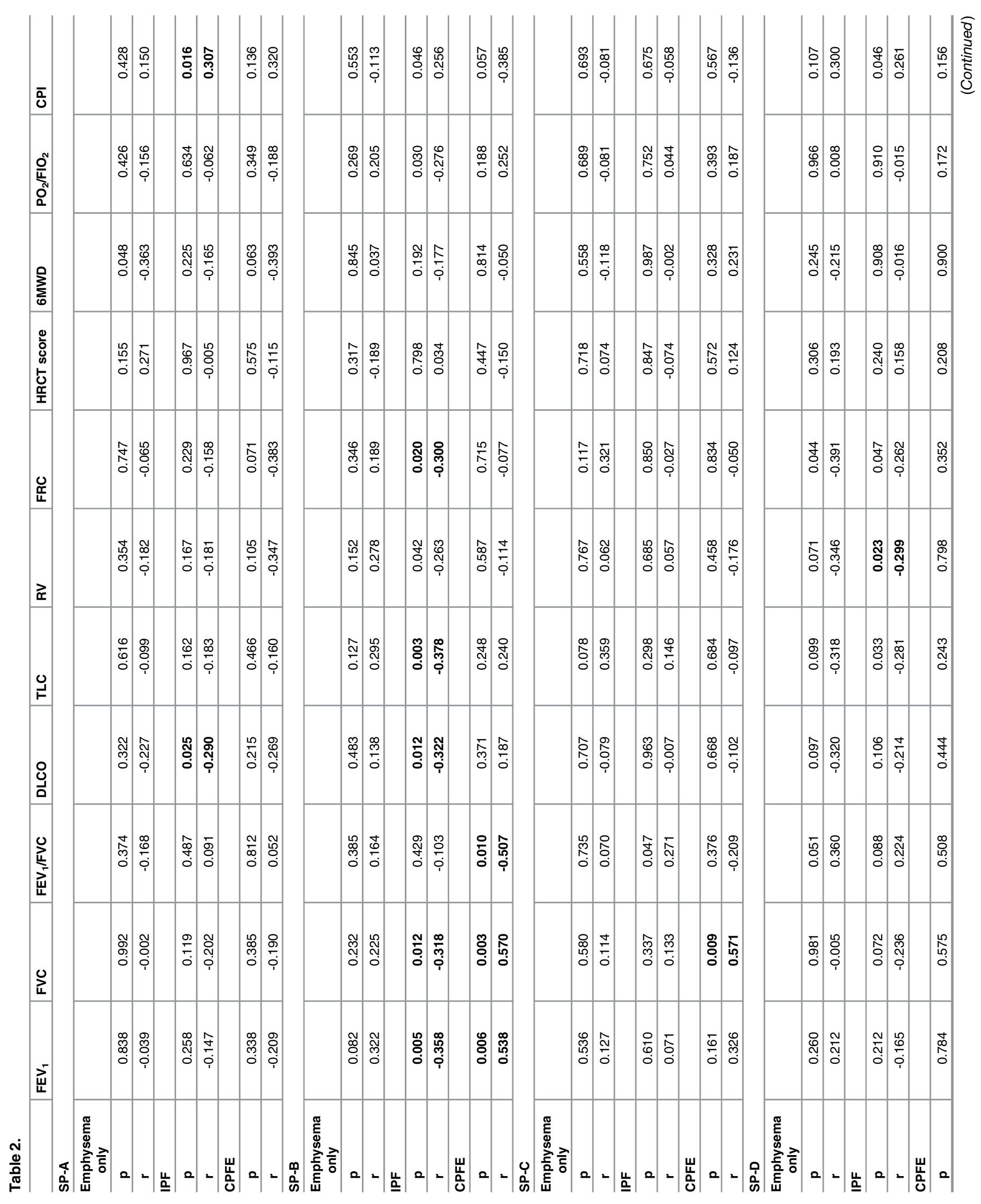




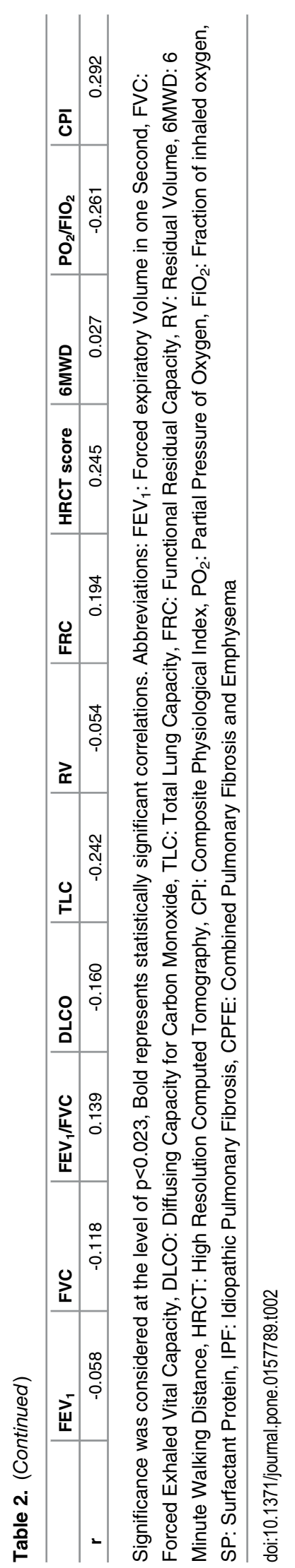


A

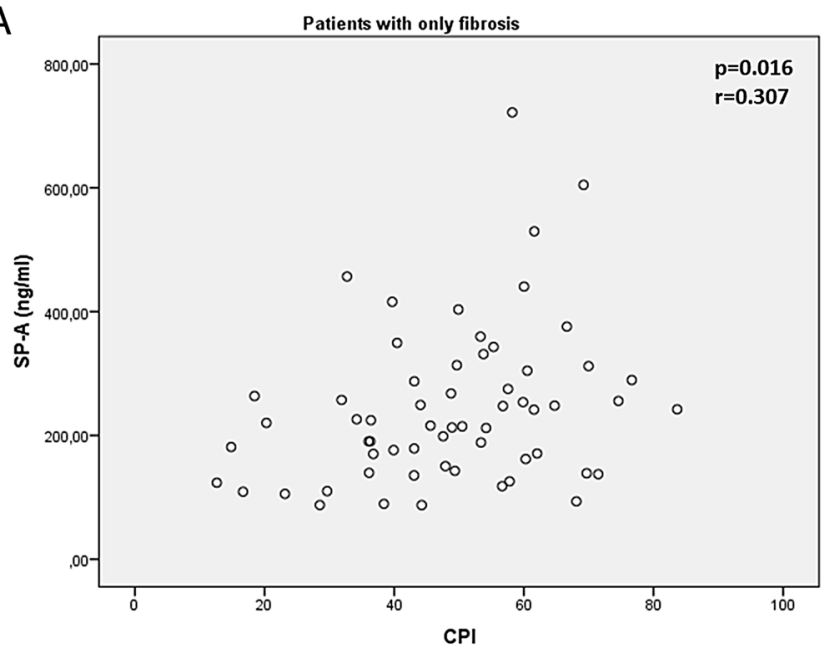

C

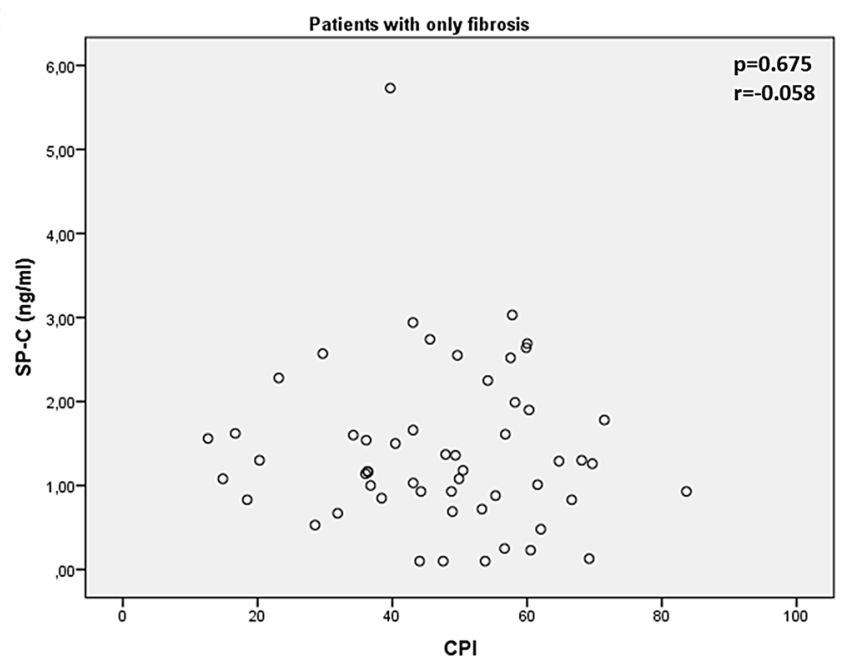

B

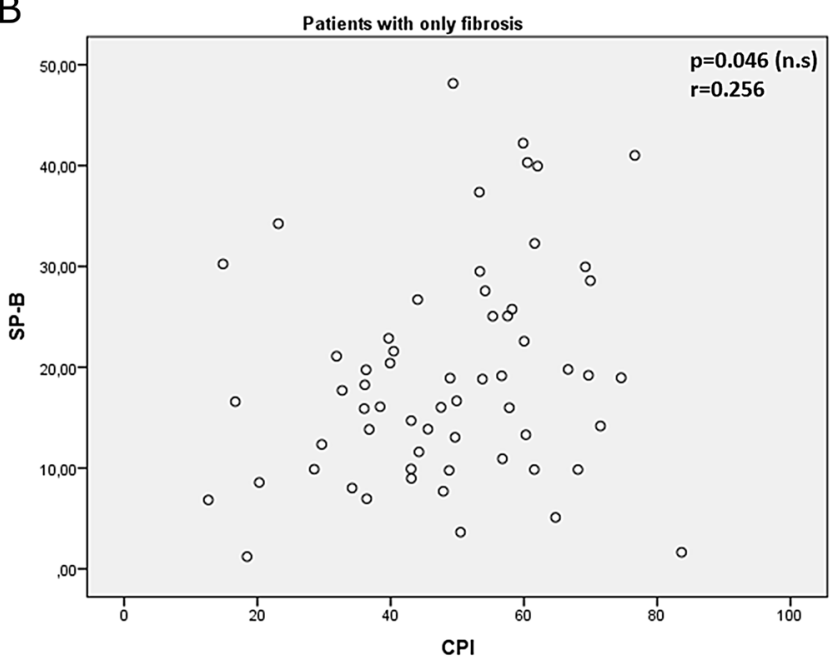

D

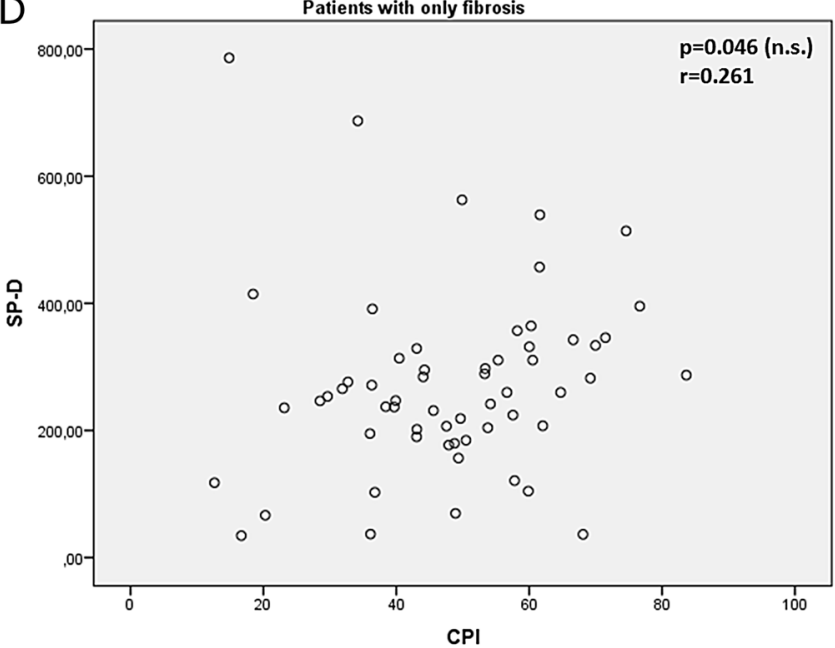

Fig 3. Composite Physiological Index (CPI) correlations to A. SP-A, B. SP-B, C. SP-C and D: SP-D. Level of statistical significance after correction for multiple correlation analysis was set at $p<0.023$.

doi:10.1371/journal.pone.0157789.g003

confirmed in our study. Our finding that serum SP-A and SP-D levels are higher in patients with fibrosis (IPF or CPFE) compared to those with only emphysema, suggests that the combination of alveolar parenchymal derangement that characterizes fibrosis with the hyperplasia of type II alveolar cells [48], may lead to the translocation of greater amounts of these SPs from the lung parenchyma to the peripheral circulation through the pulmonary vasculature in these patients.

However, the fact that patients with CPFE and more extensive emphysematous lesions in HRCT also expressed significantly higher levels of both SP-A and SP-D, might suggest that the emphysematous component on top of the fibrotic process, stretched and overdistended by the nearby fibrotic lesions, also contributes through an alveolar damage to the elevation of SP levels in these patients [49-51]. Interestingly, in our study circulating levels of SP-A, correlated to CPI in patients with IPF, CPI being a composite score found to be an important indicator of the total respiratory impairment in IPF and related to the total extent of fibrosis in these patients [37]. Although in patients with fibrosis, CPI has been acknowledged as a predictor of 


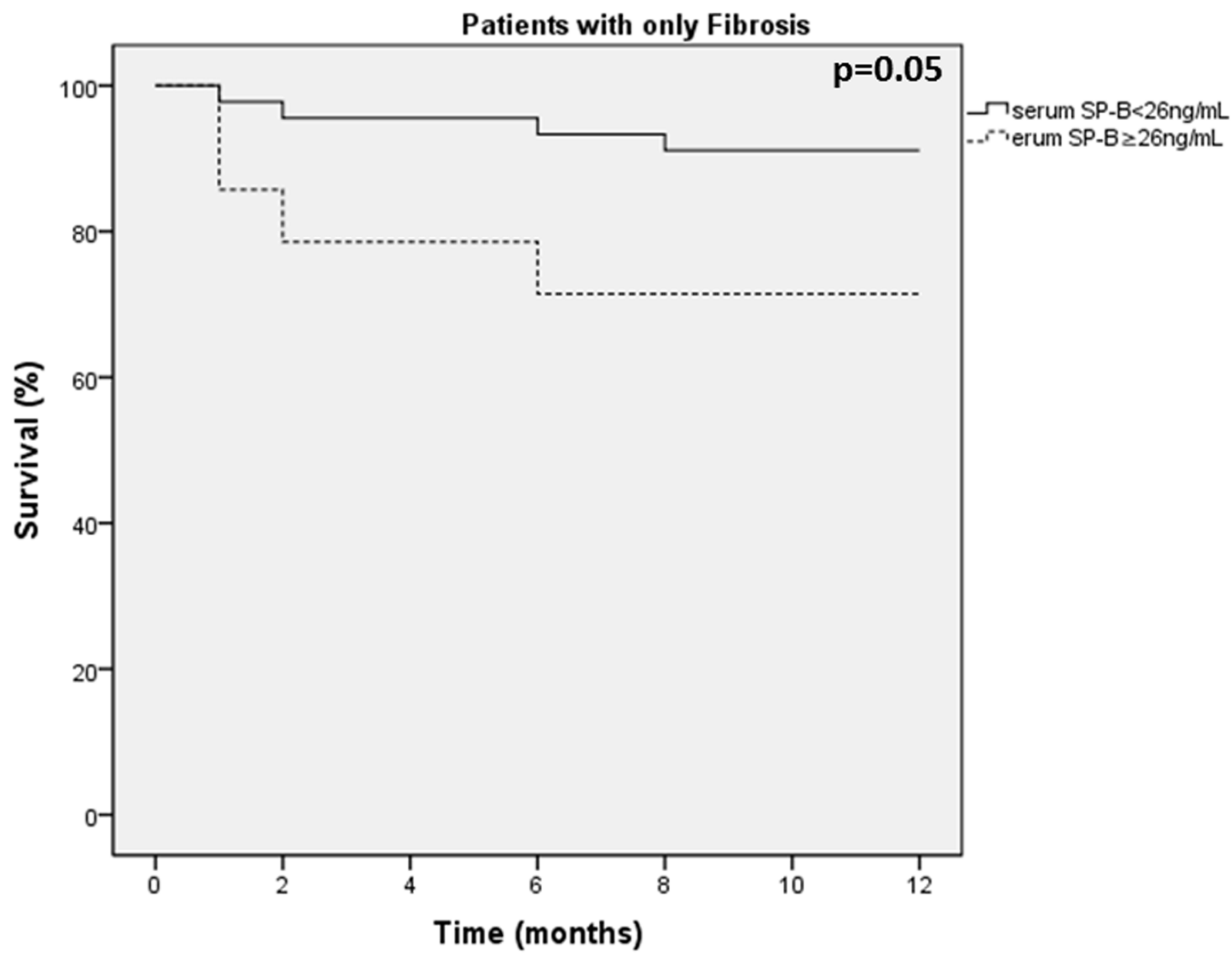

Fig 4. Kaplan-Meier curve showing survival of patients with IPF according to the levels of SP-B.

doi:10.1371/journal.pone.0157789.g004

survival, this was not the case in patients with CPFE [36], which probably explains the lack of any significant correlation of SPs with CPI in this group in our study.

Furthermore, in our control group, we have observed that healthy current smokers had higher serum levels of SP-A and SP-D compared to current non-smokers (including both never and ex-smokers). This is in accordance to previous studies showing that smokers had decreased levels of SP-A and SP-D in the bronchoalveolar lavage (BAL) fluid [52] although they seemed to express higher circulating levels of the former [53]. A possible explanation of these findings was that smokers may present an alveolo-capillary leakage of surfactant proteins into the blood [54]. The fact that serum levels of SP-A are higher in current smokers compared to ex-smokers [55], also observed in our cohort, might also represent the ongoing lung inflammation caused by cigarette smoke which leads to increased vascular permeability and to SP-A and SP-D translocation from the pulmonary compartment to the circulation [56]. It is known that smoking cessation seems to rapidly restore the alveolar-capillary barrier integrity [57] and this is probably the reason why healthy ex-smokers presented with similar serum levels of 
A

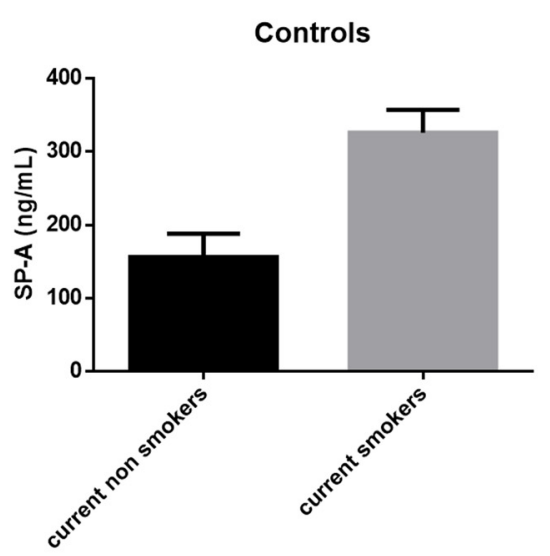

B

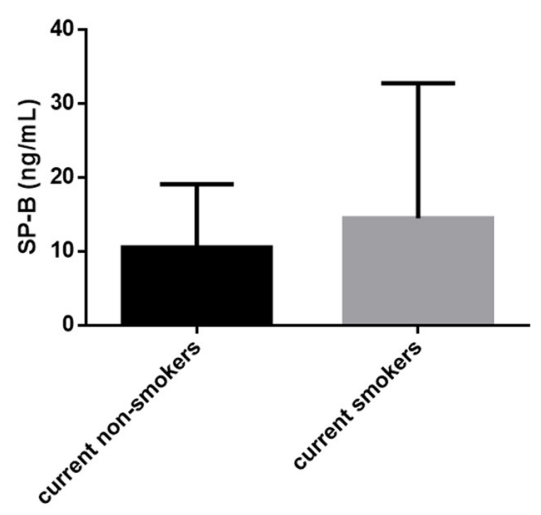

C

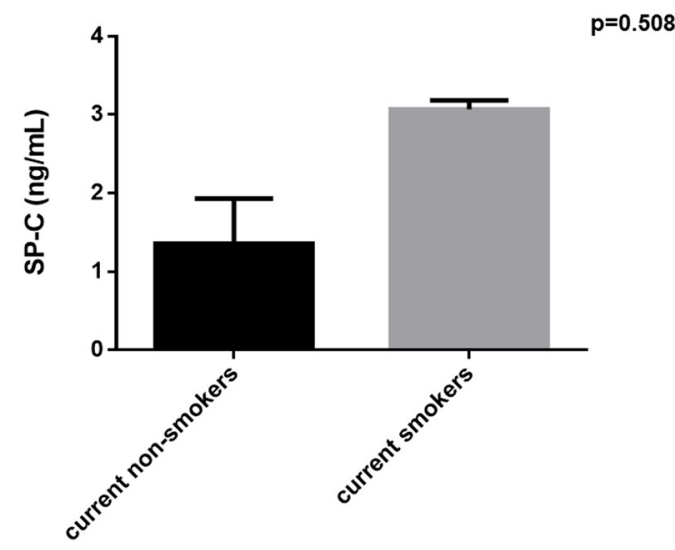

$\mathrm{p}=0.026$

$p=0.300$

D

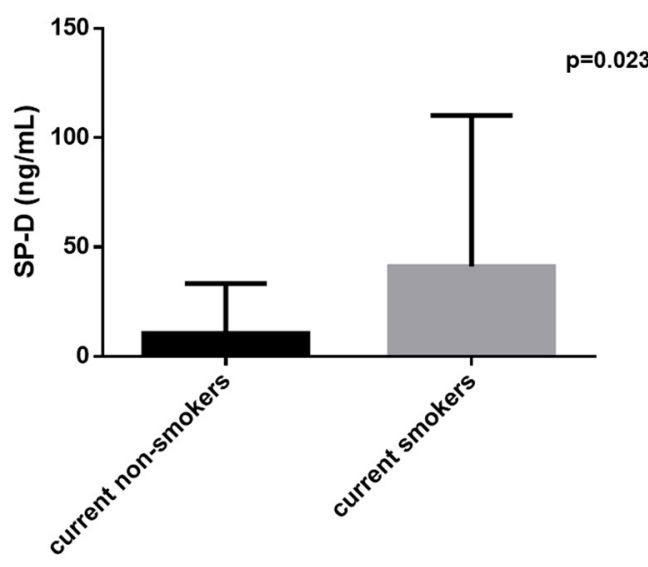

Fig 5. Serum surfactant protein levels in control subjects according to current smoking habit (current non-smokers $\mathrm{N}=16$ and current smokers $\mathbf{N}=9$ ). A. SP-A, B. SP-B, C. SP-C, D. SP-D.

doi:10.1371/journal.pone.0157789.g005

SP-A and SP-D. However, this was not the case in patients with emphysema, fibrosis or CPFE in which circulating SP levels did not differ between current smokers and current non-smokers and it seems that the established lung inflammation in both pulmonary emphysema [58-61] and fibrosis [62-65] continues despite smoking cessation. Increased serum SP-A and SP-D levels in current smokers might be an early indicator of an ongoing parenchymal damage which might lead to the development of lung disease.

Regarding SP-B, although its blood levels did not differ among groups, in patients with fibrosis we found a correlation with both individual indices of disease severity and extent such as FVC and DLCO, and in addition a marginal difference in survival, with patients with SP-B levels at the higher quartile presenting lower survival. This finding is in accordance to previous studies showing the relation of SP-B with the development of interstitial lung disease in both animals [66] and humans [67]. FVC and DLCO are known to be significant predictors of survival in IPF $[68,69]$ and this might explain the weak association between serum SP-B levels and mortality in this group of patients in our study. The mortality findings related to the increased SP-B levels, however, need to be further validated in larger studies. 


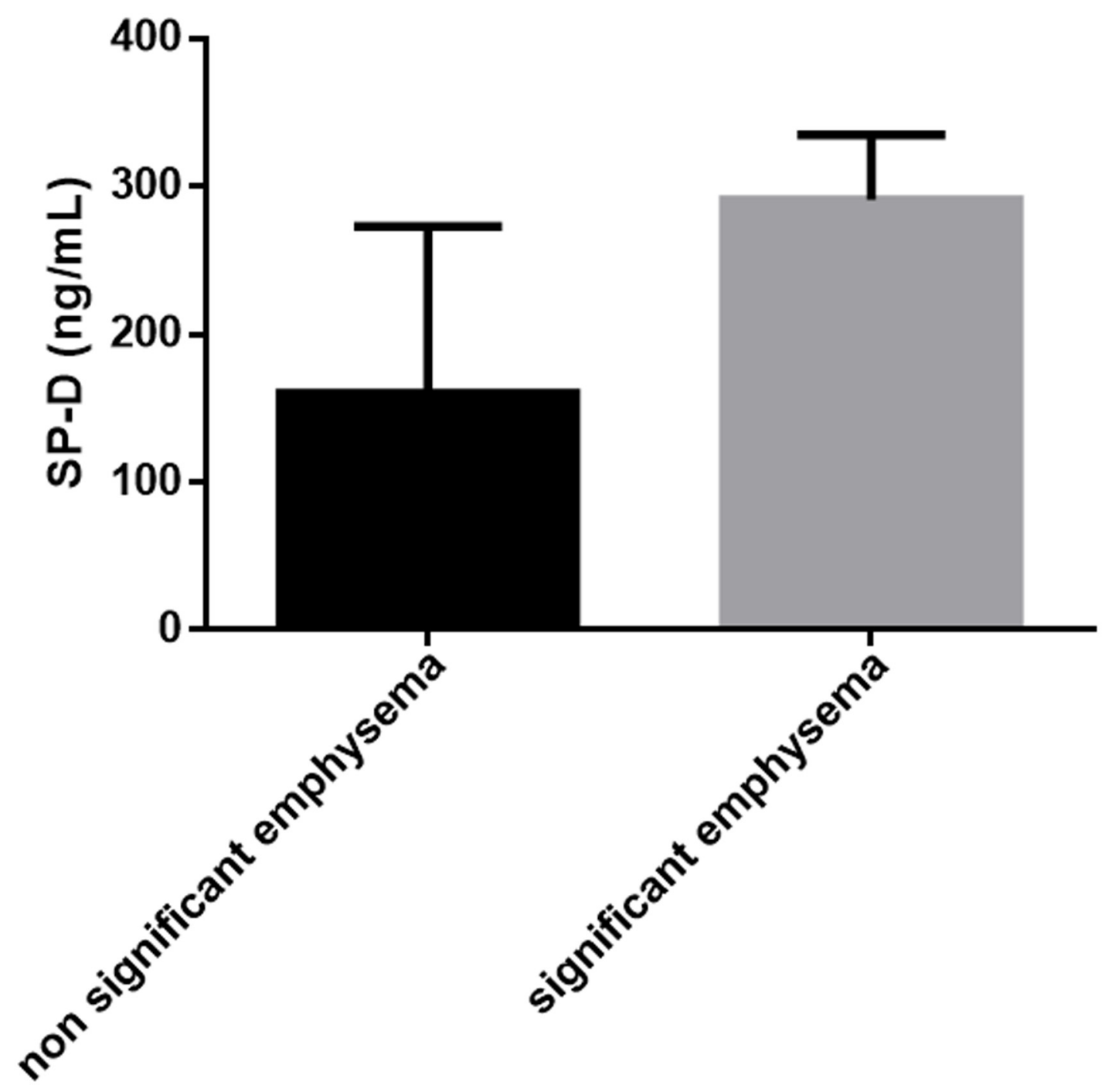

$p=0.042$

Fig 6. Serum Surfactant Protein levels in CPFE patients according to the extent of emphysematous lesions.

doi:10.1371/journal.pone.0157789.g006

Finally regarding SP-C there is some evidence that might play a role in the development of CPFE $[30,31]$ and patients with lung disease comparable with CPFE were found to have mutations in the SP-C gene [32,33]. It is important to mention that in our group of patients, serum levels of SP-C did not differ in patients with CPFE and were not associated with any disease characteristic including pulmonary function impairment, and the extent of fibrosis. The lack of such an association might relate to fact that SP-C gene mutations possibly result to functional rather than quantitative alterations of SP-C [70].

Our study has significant limitations. First, we have used an observational method for the quantification of fibrosis and/or emphysema in HRCT, instead of dedicated CT software. However, this method presents excellent correlation with densitometry quantitation $[39,40]$ and can be performed in everyday clinical practice. Second, patients were followed up for only one year which is probably the reason for the lack for any significant associations regarding SPs and survival in patients with emphysema and CPFE. Finally, it is a fact that SP-A and SP-D are additionally produced in several extrapulmonary locations, including the brain, the salivary 
glands, the heart, the kidneys and the reproductive tract [71] and for this reason we cannot confirm that the levels that are measured in serum directly originate from the lung. However, since the greater amounts of all four surfactant proteins are synthesized by alveolar type II cells and SP-A, SP-B and SP-D are also produced by different types of airway cells, including Clara cells and submucosal cells, we can conclude that the major source of serum SP levels comes from the pulmonary epithelium.

In conclusion, in this study including controls, emphysema, IPF, and CPFE patients we have shown that serum SP- A and SP-D present significantly higher serum levels where fibrosis exists or coexists while serum SP-A levels are also related to fibrosis severity and extent as reflected by the CPI score of estimation of disease severity. The above findings might suggest that serum SP-A and SP-D levels are related to the type of alveolar damage installed on fibrotic lungs and reflect their overproduction due to hyperplasia of type II alveolar cells, or overleakage in the systemic circulation caused by alveolar basement membrane splintering off and hyperpermeability. In IPF also SP-B relates to survival. Further studies are needed to define the role of the above SPs as markers of disease severity.

\section{Author Contributions}

Contributed reagents/materials/analysis tools: GP AR AM IT IP SL KC. Wrote the paper: AIP KK EM SP. Performed the samples measurement and results interpretation: AS PK. Performed the statistical analysis: AIP MG.

\section{References}

1. Cottin V, Nunes H, Brillet PY, Delaval $P$, Devouassoux G, Tillie-Leblond I, et al. Combined pulmonary fibrosis and emphysema: a distinct underrecognised entity. Eur Respir J. 2005; 26(4):586-93. Epub 2005/10/06. doi: 10.1183/09031936.05.00021005 PMID: 16204587.

2. Raghu G, Collard HR, Egan JJ, Martinez FJ, Behr J, Brown KK, et al. An official ATS/ERS/JRS/ALAT statement: idiopathic pulmonary fibrosis: evidence-based guidelines for diagnosis and management. Am J Respir Crit Care Med. 2011; 183(6):788-824. Epub 2011/04/08. doi: 10.1164/rccm.2009-040GL PMID: 21471066.

3. Celli BR, MacNee W. Standards for the diagnosis and treatment of patients with COPD: a summary of the ATS/ERS position paper. Eur Respir J. 2004; 23(6):932-46. Epub 2004/06/29. PMID: 15219010.

4. Papiris SA, Triantafillidou C, Manali ED, Kolilekas L, Baou K, Kagouridis K, et al. Combined pulmonary fibrosis and emphysema. Expert Rev Respir Med. 2013; 7(1):19-31; quiz 2. Epub 2013/02/01. doi: 10. 1586/ers.12.80 PMID: 23362797.

5. Cottin V, Nunes H, Mouthon L, Gamondes D, Lazor R, Hachulla E, et al. Combined pulmonary fibrosis and emphysema syndrome in connective tissue disease. Arthritis Rheum. 2011; 63(1):295-304. Epub 2010/10/12. doi: 10.1002/art.30077 PMID: 20936629.

6. Devendra G, Spragg RG. Lung surfactant in subacute pulmonary disease. Respir Res. 2002; 3:19. Epub 2002/05/01. PMID: 11980588; PubMed Central PMCID: PMC107848.

7. Griese M. Pulmonary surfactant in health and human lung diseases: state of the art. Eur Respir J. 1999; 13(6):1455-76. Epub 1999/08/13. PMID: 10445627.

8. Whitsett JA, Wert SE, Weaver TE. Alveolar surfactant homeostasis and the pathogenesis of pulmonary disease. Annu Rev Med. 2010; 61:105-19. Epub 2009/10/15. doi: 10.1146/annurev.med.60.041807. 123500 PMID: 19824815.

9. Akella A, Deshpande SB. Pulmonary surfactants and their role in pathophysiology of lung disorders. Indian J Exp Biol. 2013; 51(1):5-22. Epub 2013/02/28. PMID: 23441475.

10. Guo X, Lin HM, Lin Z, Montano M, Sansores R, Wang G, et al. Surfactant protein gene A, B, and D marker alleles in chronic obstructive pulmonary disease of a Mexican population. Eur Respir J. 2001; 18(3):482-90. Epub 2001/10/09. PMID: 11589345.

11. Baekvad-Hansen M, Dahl M, Tybjaerg-Hansen A, Nordestgaard BG. Surfactant protein-B 121 ins2 heterozygosity, reduced pulmonary function, and chronic obstructive pulmonary disease in smokers. Am J Respir Crit Care Med. 2010; 181(1):17-20. Epub 2009/10/17. doi: 10.1164/rccm.200906-0963OC PMID: 19833825. 
12. Baekvad-Hansen $M$, Nordestgaard BG, Dahl M. Surfactant protein B polymorphisms, pulmonary function and COPD in 10,231 individuals. Eur Respir J. 2011; 37(4):791-9. Epub 2010/08/10. doi: 10.1183/ 09031936.00026410 PMID: 20693256.

13. Foreman MG, DeMeo DL, Hersh CP, Carey VJ, Fan VS, Reilly JJ, et al. Polymorphic variation in surfactant protein B is associated with COPD exacerbations. Eur Respir J. 2008; 32(4):938-44. Epub 2008/ 06/14. doi: 10.1183/09031936.00040208 PMID: 18550614; PubMed Central PMCID: PMC2761762.

14. Baekvad-Hansen M, Nordestgaard BG, Tybjaerg-Hansen A, Dahl M. Two novel mutations in surfactant protein-C, lung function and obstructive lung disease. Respir Med. 2010; 104(3):418-25. Epub 2009/ 11/17. doi: 10.1016/j.rmed.2009.10.012 PMID: 19910179.

15. Ozyurek BA, Ulasli SS, Bozbas SS, Bayraktar N, Akcay S. Value of serum and induced sputum surfactant protein-D in chronic obstructive pulmonary disease. Multidiscip Respir Med. 2013; 8(1):36. Epub 2013/06/04. doi: 10.1186/2049-6958-8-36 PMID: 23725346; PubMed Central PMCID: PMC3670831.

16. Sin DD, Leung R, Gan WQ, Man SP. Circulating surfactant protein $D$ as a potential lung-specific biomarker of health outcomes in COPD: a pilot study. BMC Pulm Med. 2007; 7:13. Epub 2007/10/10. doi: 10.1186/1471-2466-7-13 PMID: 17922919; PubMed Central PMCID: PMC2096624.

17. Ilumets $\mathrm{H}$, Mazur W, Toljamo T, Louhelainen N, Nieminen $\mathrm{P}$, Kobayashi $\mathrm{H}$, et al. Ageing and smoking contribute to plasma surfactant proteins and protease imbalance with correlations to airway obstruction. BMC Pulm Med. 2011; 11:19. Epub 2011/04/21. doi: 10.1186/1471-2466-11-19 PMID: 21504569; PubMed Central PMCID: PMC3103485.

18. Devine MS, Garcia CK. Genetic interstitial lung disease. Clin Chest Med. 2012; 33(1):95-110. Epub 2012/03/01. doi: 10.1016/j.ccm.2011.11.001 PMID: 22365249; PubMed Central PMCID: PMC3292740.

19. Lawson WE, Grant SW, Ambrosini V, Womble KE, Dawson EP, Lane KB, et al. Genetic mutations in surfactant protein $C$ are a rare cause of sporadic cases of IPF. Thorax. 2004; 59(11):977-80. Epub 2004/11/02. doi: 10.1136/thx.2004.026336 PMID: 15516475; PubMed Central PMCID: PMC1746860.

20. Nogee LM, Dunbar AE 3rd, Wert S, Askin F, Hamvas A, Whitsett JA. Mutations in the surfactant protein C gene associated with interstitial lung disease. Chest. 2002; 121(3 Suppl):20S-1S. Epub 2002/03/15. PMID: 11893657.

21. Nogee LM, Dunbar AE 3rd, Wert SE, Askin F, Hamvas A, Whitsett JA. A mutation in the surfactant protein C gene associated with familial interstitial lung disease. N Engl J Med. 2001; 344(8):573-9. Epub 2001/02/24. doi: 10.1056/nejm200102223440805 PMID: 11207353.

22. Amin RS, Wert SE, Baughman RP, Tomashefski JF Jr, Nogee LM, Brody AS, et al. Surfactant protein deficiency in familial interstitial lung disease. J Pediatr. 2001; 139(1):85-92. Epub 2001/07/11. doi: 10. 1067/mpd.2001.114545 PMID: 11445799.

23. Thomas AQ, Lane K, Phillips J 3rd, Prince M, Markin C, Speer M, et al. Heterozygosity for a surfactant protein $\mathrm{C}$ gene mutation associated with usual interstitial pneumonitis and cellular nonspecific interstitial pneumonitis in one kindred. Am J Respir Crit Care Med. 2002; 165(9):1322-8. Epub 2002/05/07. doi: 10.1164/rccm.200112-1230C PMID: 11991887.

24. Samukawa T, Hamada T, Uto H, Yanagi M, Tsukuya G, Nosaki T, et al. The elevation of serum napsin A in idiopathic pulmonary fibrosis, compared with KL-6, surfactant protein-A and surfactant protein-D. BMC Pulm Med. 2012; 12:55. Epub 2012/09/12. doi: 10.1186/1471-2466-12-55 PMID: 22963039; PubMed Central PMCID: PMC3515468.

25. Barlo NP, van Moorsel CH, Ruven HJ, Zanen P, van den Bosch JM, Grutters JC. Surfactant protein-D predicts survival in patients with idiopathic pulmonary fibrosis. Sarcoidosis Vasc Diffuse Lung Dis. 2009; 26(2):155-61. Epub 2010/06/22. PMID: 20560296.

26. Takahashi H, Fujishima T, Koba H, Murakami S, Kurokawa K, Shibuya Y, et al. Serum surfactant proteins $A$ and $D$ as prognostic factors in idiopathic pulmonary fibrosis and their relationship to disease extent. Am J Respir Crit Care Med. 2000; 162(3 Pt 1):1109-14. Epub 2000/09/16. doi: 10.1164/ajrccm. 162.3.9910080 PMID: 10988138.

27. Greene KE, King TE Jr, Kuroki Y, Bucher-Bartelson B, Hunninghake GW, Newman LS, et al. Serum surfactant proteins-A and -D as biomarkers in idiopathic pulmonary fibrosis. Eur Respir J. 2002; 19 (3):439-46. Epub 2002/04/09. PMID: 11936520.

28. Kinder BW, Brown KK, McCormack FX, Ix JH, Kervitsky A, Schwarz MI, et al. Serum surfactant proteinA is a strong predictor of early mortality in idiopathic pulmonary fibrosis. Chest. 2009; 135(6):1557-63. Epub 2009/03/04. doi: 10.1378/chest.08-2209 PMID: 19255294; PubMed Central PMCID: PMC2716710.

29. Travis WD, Costabel U, Hansell DM, King TE Jr, Lynch DA, Nicholson AG, et al. An official American Thoracic Society/European Respiratory Society statement: Update of the international multidisciplinary classification of the idiopathic interstitial pneumonias. Am J Respir Crit Care Med. 2013; 188(6):73348. Epub 2013/09/17. doi: 10.1164/rccm.201308-1483ST PMID: 24032382. 
30. Cottin V, Reix P, Khouatra C, Thivolet-Bejui F, Feldmann D, Cordier JF. Combined pulmonary fibrosis and emphysema syndrome associated with familial SFTPC mutation. Thorax. 2011; 66(10):918-9. Epub 2011/01/21. doi: 10.1136/thx.2010.151407 PMID: 21248320.

31. Lundblad LK, Thompson-Figueroa J, Leclair T, Sullivan MJ, Poynter ME, Irvin CG, et al. Tumor necrosis factor-alpha overexpression in lung disease: a single cause behind a complex phenotype. Am J Respir Crit Care Med. 2005; 171(12):1363-70. Epub 2005/04/05. doi: 10.1164/rccm.200410-13490C PMID: 15805183; PubMed Central PMCID: PMC2718479.

32. van Moorsel $\mathrm{CH}$, van Oosterhout MF, Barlo NP, de Jong PA, van der Vis JJ, Ruven HJ, et al. Surfactant protein $\mathrm{C}$ mutations are the basis of a significant portion of adult familial pulmonary fibrosis in a dutch cohort. Am J Respir Crit Care Med. 2010; 182(11):1419-25. Epub 2010/07/27. doi: 10.1164/rccm. 200906-09530C PMID: 20656946.

33. Cottin V, Cordier JF. SFTPC mutations in patients with familial pulmonary fibrosis: combined with emphysema? Am J Respir Crit Care Med. 2011; 183(8):1113; author reply -4. Epub 2011/04/19. doi: 10.1164/ajrccm.183.8.1113a PMID: 21498825.

34. Chiba S, Ohta H, Abe K, Hisata S, Ohkouchi S, Hoshikawa Y, et al. The Diagnostic Value of the Interstitial Biomarkers KL-6 and SP-D for the Degree of Fibrosis in Combined Pulmonary Fibrosis and Emphysema. Pulm Med. 2012; 2012:492960. Epub 2012/04/25. doi: 10.1155/2012/492960 PMID: 22530118; PubMed Central PMCID: PMC3316999.

35. Standardization of Spirometry, 1994 Update. American Thoracic Society. Am J Respir Crit Care Med. 1995; 152(3):1107-36. PMID: 7663792.

36. Schmidt SL, Nambiar AM, Tayob N, Sundaram B, Han MK, Gross BH, et al. Pulmonary function measures predict mortality differently in IPF versus combined pulmonary fibrosis and emphysema. Eur Respir J. 2011; 38(1):176-83. Epub 2010/12/15. doi: 10.1183/09031936.00114010 PMID: 21148225.

37. Wells AU, Desai SR, Rubens MB, Goh NS, Cramer D, Nicholson AG, et al. Idiopathic pulmonary fibrosis: a composite physiologic index derived from disease extent observed by computed tomography. Am J Respir Crit Care Med. 2003; 167(7):962-9. Epub 2003/03/29. doi: 10.1164/rccm.2111053 PMID: 12663338 .

38. Celli BR, Cote CG, Marin JM, Casanova C, Montes de Oca M, Mendez RA, et al. The body-mass index, airflow obstruction, dyspnea, and exercise capacity index in chronic obstructive pulmonary disease. $\mathrm{N}$ Engl J Med. 2004; 350(10):1005-12. PMID: 14999112.

39. Park KJ, Bergin CJ, Clausen JL. Quantitation of emphysema with three-dimensional CT densitometry: comparison with two-dimensional analysis, visual emphysema scores, and pulmonary function test results. Radiology. 1999; 211(2):541-7. Epub 1999/05/06. PMID: 10228540.

40. Kim HG, Tashkin DP, Clements PJ, Li G, Brown MS, Elashoff R, et al. A computer-aided diagnosis system for quantitative scoring of extent of lung fibrosis in scleroderma patients. Clin Exp Rheumatol. 2010; 28(5 Suppl 62):S26-35. Epub 2010/11/26. PMID: 21050542; PubMed Central PMCID: PMC3177564.

41. Matsuoka S, Yamashiro T, Matsushita S, Fujikawa A, Kotoku A, Yagihashi K, et al. Morphological disease progression of combined pulmonary fibrosis and emphysema: comparison with emphysema alone and pulmonary fibrosis alone. J Comput Assist Tomogr. 2015; 39(2):153-9. Epub 2014/12/05. doi: 10.1097/rct.0000000000000184 PMID: 25474146.

42. Boschetto $P$, Quintavalle S, Zeni E, Leprotti S, Potena A, Ballerin L, et al. Association between markers of emphysema and more severe chronic obstructive pulmonary disease. Thorax. 2006; 61(12):103742. PMID: 16769715.

43. Papaioannou AI, Mazioti A, Kiropoulos T, Tsilioni I, Koutsokera A, Tanou K, et al. Systemic and airway inflammation and the presence of emphysema in patients with COPD. Respir Med. 2010; 104(2):27582. Epub 2009/10/27. doi: 10.1016/j.rmed.2009.09.016 PMID: 19854037.

44. Mahler DA, Wells CK. Evaluation of clinical methods for rating dyspnea. Chest. 1988; 93(3):580-6. PMID: 3342669.

45. ATS statement: guidelines for the six-minute walk test. Am J Respir Crit Care Med. 2002; 166(1):1117. PMID: 12091180.

46. Benjamini Y, Hochberg Y. Controlling the False Discovery Rate: A Practical and Powerful Approach to Multiple Testing. Journal of the Royal Statistical Society. 1995; 57(1):289-300.

47. Honda $Y$, Kuroki $Y$, Matsuura E, Nagae H, Takahashi $H$, Akino $T$, et al. Pulmonary surfactant protein D in sera and bronchoalveolar lavage fluids. Am J Respir Crit Care Med. 1995; 152(6 Pt 1):1860-6. Epub 1995/12/01. doi: 10.1164/ajrccm.152.6.8520747 PMID: 8520747.

48. Selman M, Pardo A. Role of epithelial cells in idiopathic pulmonary fibrosis: from innocent targets to serial killers. Proc Am Thorac Soc. 2006; 3(4):364-72. Epub 2006/06/02. doi: 10.1513/pats.200601003TK PMID: 16738202. 
49. Froese AR, Shimbori C, Bellaye PS, Ask K, Inman M, Obex S, et al. Stretch Induced Activation of TGFbeta1 in Pulmonary Fibrosis. Am J Respir Crit Care Med. 2016. Epub 2016/01/16. doi: 10.1164/rccm. 201508-16380C PMID: 26771871.

50. Hinz B. Mechanical aspects of lung fibrosis: a spotlight on the myofibroblast. Proc Am Thorac Soc. 2012; 9(3):137-47. Epub 2012/07/18. doi: 10.1513/pats.201202-017AW PMID: 22802288.

51. Lutz D, Gazdhar A, Lopez-Rodriguez E, Ruppert C, Mahavadi P, Gunther A, et al. Alveolar derecruitment and collapse induration as crucial mechanisms in lung injury and fibrosis. Am J Respir Cell Mol Biol. 2015; 52(2):232-43. Epub 2014/07/18. doi: 10.1165/rcmb.2014-0078OC PMID: 25033427.

52. Honda $\mathrm{Y}$, Takahashi $\mathrm{H}$, Kuroki $\mathrm{Y}$, Akino $\mathrm{T}$, Abe $\mathrm{S}$. Decreased contents of surfactant proteins $\mathrm{A}$ and $\mathrm{D}$ in BAL fluids of healthy smokers. Chest. 1996; 109(4):1006-9. Epub 1996/04/01. PMID: 8635323.

53. Mazur W, Toljamo T, Ohlmeier S, Vuopala K, Nieminen P, Kobayashi H, et al. Elevation of surfactant protein A in plasma and sputum in cigarette smokers. Eur Respir J. 2011; 38(2):277-84. Epub 2011/01/ 29. doi: 10.1183/09031936.00110510 PMID: 21273386.

54. Hermans $C$, Bernard A. Lung epithelium-specific proteins: characteristics and potential applications as markers. Am J Respir Crit Care Med. 1999; 159(2):646-78. Epub 1999/02/02. doi: 10.1164/ajrccm. 159.2.9806064 PMID: 9927386.

55. Kobayashi H, Kanoh S, Motoyoshi K. Serum surfactant protein-A, but not surfactant protein-D or KL-6, can predict preclinical lung damage induced by smoking. Biomarkers. 2008; 13(4):385-92. Epub 2008/ 07/04. doi: 10.1080/13547500801903651 PMID: 18595202.

56. Jaw JE, Sin DD. Unifying thoracic biomarkers: surfactant protein-D and beyond. Expert Rev Respir Med. 2012; 6(2):147-54. Epub 2012/03/30. doi: 10.1586/ers.12.5 PMID: 22455487.

57. Mason GR, Uszler JM, Effros RM, Reid E. Rapidly reversible alterations of pulmonary epithelial permeability induced by smoking. Chest. 1983; 83(1):6-11. Epub 1983/01/01. PMID: 6336690.

58. Willemse BW, ten Hacken NH, Rutgers B, Lesman-Leegte IG, Postma DS, Timens W. Effect of 1-year smoking cessation on airway inflammation in COPD and asymptomatic smokers. Eur Respir J. 2005; 26(5):835-45. Epub 2005/11/03. doi: 10.1183/09031936.05.00108904 PMID: 16264044.

59. Miller M, Cho JY, Pham A, Friedman PJ, Ramsdell J, Broide DH. Persistent airway inflammation and emphysema progression on CT scan in ex-smokers observed for 4 years. Chest. 2011; 139(6):1380-7. Epub 2010/10/23. doi: 10.1378/chest.10-0705 PMID: 20966041; PubMed Central PMCID: PMC3109645.

60. Lapperre TS, Postma DS, Gosman MM, Snoeck-Stroband JB, ten Hacken NH, Hiemstra PS, et al. Relation between duration of smoking cessation and bronchial inflammation in COPD. Thorax. 2006; 61(2):115-21. Epub 2005/08/02. doi: 10.1136/thx.2005.040519 PMID: 16055612; PubMed Central PMCID: PMC2104584.

61. Hogg JC. Why does airway inflammation persist after the smoking stops? Thorax. 2006; 61(2):96-7. Epub 2006/01/31. doi: 10.1136/thx.2005.049502 PMID: 16443703; PubMed Central PMCID: PMC2104586.

62. Daniil Z, Kitsanta P, Kapotsis G, Mathioudaki M, Kollintza A, Karatza M, et al. CD8+ T lymphocytes in lung tissue from patients with idiopathic pulmonary fibrosis. Respir Res. 2005; 6:81. Epub 2005/07/27. doi: 10.1186/1465-9921-6-81 PMID: 16042790; PubMed Central PMCID: PMC1199622.

63. King TE Jr, Pardo A, Selman M. Idiopathic pulmonary fibrosis. Lancet. 2011; 378(9807):1949-61. Epub 2011/07/02. doi: 10.1016/s0140-6736(11)60052-4 PMID: 21719092

64. Kolb M, Margetts PJ, Anthony DC, Pitossi F, Gauldie J. Transient expression of IL-1beta induces acute lung injury and chronic repair leading to pulmonary fibrosis. J Clin Invest. 2001; 107(12):1529-36. Epub 2001/06/20. doi: 10.1172/jci12568 PMID: 11413160; PubMed Central PMCID: PMC200196.

65. Selman M, King TE, Pardo A. Idiopathic pulmonary fibrosis: prevailing and evolving hypotheses about its pathogenesis and implications for therapy. Ann Intern Med. 2001; 134(2):136-51. Epub 2001/02/15. PMID: 11177318.

66. Dunbar AE 3rd, Wert SE, Ikegami M, Whitsett JA, Hamvas A, White FV, et al. Prolonged survival in hereditary surfactant protein $\mathrm{B}$ (SP-B) deficiency associated with a novel splicing mutation. Pediatr Res. 2000; 48(3):275-82. Epub 2000/08/29. doi: 10.1203/00006450-200009000-00003 PMID: 10960490

67. Selman M, Lin HM, Montano M, Jenkins AL, Estrada A, Lin Z, et al. Surfactant protein A and B genetic variants predispose to idiopathic pulmonary fibrosis. Hum Genet. 2003; 113(6):542-50. Epub 2003/09/ 19. doi: 10.1007/s00439-003-1015-4 PMID: 13680361.

68. Ley B, Collard HR, King TE Jr. Clinical course and prediction of survival in idiopathic pulmonary fibrosis. Am J Respir Crit Care Med. 2011; 183(4):431-40. Epub 2010/10/12. doi: 10.1164/rccm.2010060894CI PMID: 20935110. 
69. Latsi PI, du Bois RM, Nicholson AG, Colby TV, Bisirtzoglou D, Nikolakopoulou A, et al. Fibrotic idiopathic interstitial pneumonia: the prognostic value of longitudinal functional trends. Am J Respir Crit Care Med. 2003; 168(5):531-7. Epub 2003/06/07. doi: 10.1164/rccm.200210-1245OC PMID: 12791580.

70. Kropski JA, Blackwell TS, Loyd JE. The genetic basis of idiopathic pulmonary fibrosis. Eur Respir J. 2015; 45(6):1717-27. Epub 2015/04/04. doi: 10.1183/09031936.00163814 PMID: 25837031.

71. Christmann U, Buechner-Maxwell VA, Witonsky SG, Hite RD. Role of lung surfactant in respiratory disease: current knowledge in large animal medicine. J Vet Intern Med. 2009; 23(2):227-42. Epub 2009/ 02/05. doi: 10.1111/j.1939-1676.2008.0269.x PMID: 19192153. 